\title{
Study the Sensory Attributes and Shelf Life of Developed Digestive Pills from Makoi (Solanum nigrum) \\ Bimal Bibhuti* and Yadav AK
}

Department of Food Process Engineering, Vaugh School of Agricultural Engineering and Technology, Sam Higginbottom Institute of Agriculture, Technology and Sciences, Allahabad, India

\begin{abstract}
Solanum nigrum belongs to family Solanaceae. Blacknight-shade and Makoi are the common name for it. The chemical constituents commonly found in Solanum nigrum are glycoalkaloids, glycoproteins, polysaccharides, polyphenolic compounds such as gallic acid, cathechin, protocatechuic acid, caffeic acid, epicatechin, rutin etc. Solanum nigrum has very much importance as a medicinal plant. Root, whole plant and leaves are used but fruits of black colour are not used as they possess toxicity, therefore they are not used for medicinal purposes. Reddish- brown coloured fruits are used for edible purpose. It has been also extensively used in traditional medicine in India and other parts of world to cure liver disorders, digestion, chronic skin ailments, inflammatory conditions, painful periods, fevers, diarrhoea, eye disease, hydrophobia etc. Extracts prepared with using spices condiments exhibited stomach disorders and also improved digestion activity as compared to other digestive pills.
\end{abstract}

Keywords: Solanum nigrum; Medicinal; Liver disorders; Digestion; Condiments; Digestive pills

\section{Introduction}

India is the largest producer of medicinal plants and brightly called as the "Botanical garden of the world". Plant derived drugs even today remain important resource especially in developing countries to combat serious diseases. Approximately $62 \%$ to $80 \%$ of world's population still relies on traditional medicines for the treatment of common illness [1]. S. nigrum is an important ingredient in traditional Indian medicines. Infusions are used in dysentery, stomach complaints, and fever. In India, the berries are casually grown and eaten, but not cultivated for commercial use. The quest to manufacture foods for healthy benefits is an underpinning goal of the modern food industry. Food processing has evolved to carryout steps for the controlled destruction of natural food structures. These steps facilitate separation of valuable components from the original matrix in which they are embedded [2-7]. The separated ingredients are then converted into recognizable processed foods with desirable's textural and sensorial properties by application of one or more processing steps. Recent evidence indicates that how the food structure breaks down during gastric digestion significantly affects the rate of uptake of nutrients in the gastrointestinal (GI) tract. The digestion process has been well studied in terms of secretion of gastric fluids, enzymatic breakdown of fats, proteins and carbohydrates, and molecular and ionic transport across the intestinal epithelium. However, there remains a notable lack of understanding about the food disintegration kinetics and the extraction of small molecules from complex food structures in the gastric environment. The rate of food disintegration in stomach is a key factor influencing emptying rate and subsequently affecting absorption of nutrients in the intestine. Faster disintegration and emptying of drug tablets is responsible for the faster absorption of drug ingredients in the intestine. The stomach contraction, particularly terminal antral contraction, imposes a considerable mechanical destructive force on food particulates and thus is crucial on the disintegration of solids. Researchers have measured contraction forces present in the stomach ranging from $0.2 \mathrm{~N}$ to $2 \mathrm{~N}$ [8-11].

Findings from this research will provide an improved understanding of the interaction of the food matrix and active ingredients during gastric digestion. The computational modeling of the human stomach will predict the kinetics of disintegration of a food matrix under known physiological conditions of the stomach. These findings should provide new information for the food processing industry to develop structured foods for healthful benefits and develop strategies for controlled release of food nutrients at desired sites in the GI tract [12-15]. The anticipated information will enhance understanding of the stomach emptying of foods to develop approaches to control it. Control of gastric emptying is essential for ensuring optimal digestion. The rate of food disintegration in the stomach appears to be a key factor influencing emptying rate and subsequently affecting absorption of nutrients in the intestine [1623]. The potential for modulation of the rate of gastric emptying to control obesity and diabetic patients is now being explored vigorously by the pharmaceutical industry. Study of gastric disintegration of foods should also help our understanding of the interactions between food and drugs during digestion $[5,8,9]$. The disintegration activity of a drug is substantially affected by the presence of food components. Thus the understanding of food disintegration should help improve the control of pill dissolution in stomach.

Kakamachi (Solanum nigrum) is widely described in the Ayurvedic classics \& also have references in Vedas. This herb has its own erthomedical importance since it plays a significant role in the treatment of various diseases. It is having both curative \& nutritive value [21,2428]. It is used as single drug \& in compound formulations. In this research, we use different ingredients along with Solanum nigrum to increase their pharmacological properties, therapeutic or dietarg utility indigestion. Hence the project is carried out under the above objectives.

\section{Materials and Methods}

This chapter deals with the description of various materials and

${ }^{*}$ Corresponding author: Bimal Bibhuti, Department of Food Process Engineering Vaugh School of Agricultural Engineering and Technology, Sam Higginbottom Institute of Agriculture, Technology and Sciences, Allahabad, India, Tel: +919454507994; E-mail: bimalbibhuti@rediffmail.com

Received September 01, 2016; Accepted September 20, 2016; Published September 26, 2016

Citation: Bibhuti B, Yadav AK (2016) Study the Sensory Attributes and Shelf Life of Developed Digestive Pills from Makoi (Solanum nigrum). J Food Process Technol 7: 622 doi: $10.4172 / 2157-7110.1000622$

Copyright: ( 2016 Bibhuti B, et al. This is an open-access article distributed under the terms of the Creative Commons Attribution License, which permits unrestricted use, distribution, and reproduction in any medium, provided the original author and source are credited. 
Citation: Bibhuti B, Yadav AK (2016) Study the Sensory Attributes and Shelf Life of Developed Digestive Pills from Makoi (Solanum nigrum). J Food Process Technol 7: 622. doi: 10.4172/2157-7110.1000622

Page 2 of 5

methods which was used to accomplish the experimental work done to attain the desired objectives of the work entitled, Study the sensory attributes and shelf life of developed digestive pills from Makoi (Solanum nigrum). The experimental technique, materials which was used in this study and the associated methodology for product development and their sensory analysis was elaborated in this chapter. The experimental plan was shown in Table 1 with different variables, levels and description [27-31].

From the above formula, the development of product from different treatments were done and in these treatments the treatment $\mathrm{T}_{1}$ was widely accepted by the judgers and the further experiments were carried-out by using this formula [32-35] (Table 2). According to the judger's confirmation for treatment $\mathrm{T}_{1}$, the alteration in moisture were calculated and by this alteration the total effect on the Physico-chemical properties of the developed product was estimated (as $R_{1}, R_{2}$ and $R_{3}$ ) and the mean value of the data for the product was selected which were given as follows. All the Physico-chemical values were calculated as per $100 \mathrm{~g}$ of the developed product (Table 3).

\section{Methods}

After the development of the product, the pills were further brought for study the sensory attributes and storage conditions from the following methods which were explained follows:
Organoleptic evaluation: Sensory attributes including colour, aroma, taste and overall acceptability was determined by hedonic rating tastes as recommended by Karmakar [18]. Hedonic rating taste was used for evaluation of sensory characteristics. This test was used for acceptability by consumer for the product. The detail methodology was presented below. A panel of 5 expert judges of different age group having different habit was be selected and samples were served to them [36-39]. The expert panellist was be asked to rate the acceptability of the product through sense organs on scale of nine (9) points ranging from like extremely to dislike extremely.

Packaging material: The protection offered by a package was determined by the nature of the packaging materials and by the type of package condition. A great variety of materials were used in packaging, as LDPE, HDPE and Glass bottles.

\section{Results and Discussion}

This chapter deals with the findings of the study and effect of developed pills with different spices condiments, on the parameters such as sensory attributes and shelf life of developed digestive pills from Makoi (Solanum nigrum).

\section{Sensory evaluation}

Sensory attributes including colour, taste, aroma, and overall

\begin{tabular}{|c|c|c|c|}
\hline S.no. & Variables/ Parameters & Levels & Description \\
\hline 1 & Product & 1 & Digestive pills \\
\hline 2 & Ingredients & 8 & Makoi (Solanum nigrum), Hing, Piper longum and Tailed pepper, Ajwain, Jeera, Black Salt, \\
Imli Paste and Artificial sweetner.
\end{tabular}

Table 1: Experimental plan.

\begin{tabular}{|c|c|c|c|c|c|}
\hline \multirow{2}{*}{ Ingredients } & \multicolumn{5}{|c|}{ Treatments } \\
\hline & $\mathrm{T}_{0}$ & $\mathrm{~T}_{1}$ & $T_{2}$ & $\mathbf{T}_{3}$ & $T_{4}$ \\
\hline Makoi & $12 \%$ & $20 \%$ & $24 \%$ & $25 \%$ & $26 \%$ \\
\hline Piper longum and Tailed pepper & $5 \%$ & $4 \%$ & $3 \%$ & $3 \%$ & $3 \%$ \\
\hline Hing & $1 \%$ & $1 \%$ & $1 \%$ & $1 \%$ & $1 \%$ \\
\hline Artificial sweetner & $12 \%$ & $12 \%$ & $14 \%$ & $15 \%$ & $15 \%$ \\
\hline Ajwain & $20 \%$ & $8 \%$ & $8 \%$ & $8 \%$ & $7 \%$ \\
\hline Jeera & $15 \%$ & $10 \%$ & $10 \%$ & $8 \%$ & $8 \%$ \\
\hline Black salt & $10 \%$ & $15 \%$ & $15 \%$ & $15 \%$ & $15 \%$ \\
\hline Imli paste & $25 \%$ & $25 \%$ & $25 \%$ & $25 \%$ & $25 \%$ \\
\hline
\end{tabular}

Table 2: Experimental design.

\begin{tabular}{|c|c|c|c|}
\hline \multirow{2}{*}{ Physico-chemical properties } & \multicolumn{2}{|c|}{ Replication } & $\mathbf{R}_{\mathbf{2}}$ \\
\cline { 2 - 4 } & $\mathbf{R}_{\mathbf{1}}$ & $16.23 \%$ & $15.02 \%$ \\
\hline Moisture & $22.43 \%$ & $0.85 \%$ & $0.86 \%$ \\
\hline Protein & $0.82 \%$ & $1.97 \%$ & $1.98 \%$ \\
\hline Fat & $1.95 \%$ & $2.60 \%$ & $2.80 \%$ \\
\hline Total Ash & $2.40 \%$ & $1.69 \%$ & $1.59 \%$ \\
\hline Crude Fibre & $1.62 \%$ & $2.60 \%$ & $79.34 \%$ \\
\hline Carbohydrate & $72.40 \%$ & $1.60 \%$ & \\
\hline
\end{tabular}

Table 3: Experimental design for the developed product. 
Citation: Bibhuti B, Yadav AK (2016) Study the Sensory Attributes and Shelf Life of Developed Digestive Pills from Makoi (Solanum nigrum). J Food Process Technol 7: 622. doi: 10.4172/2157-7110.1000622

Page 3 of 5

acceptability was determined by hedonic rating tastes recommended by Hedonic rating taste which was used for evaluation of sensory characteristics. This test was used for acceptability by the consumer for the developed product [40]. The colour, taste, aroma and overall acceptability of developed digestive pills were accepted at different storage periods at ambient temperature by the judgers (Tables 4-6). Effect of packaging materials and ambient storage period on sensory evaluation of developed digestive pills [41,42] (Figures 1-3).

\section{Summary}

This present study on sensory attributes and shelf life of developed digestive pills from Makoi (Solanum nigrum) was undertaken in the Department of Food Process and Engineering, Vaugh school of Agricultural Engineering and Technology, Sam Higgin bottom Institute of Agriculture, Technology and Sciences Allahabad. In the present investigation efforts were made to develop the digestive pills

\begin{tabular}{|c|c|c|c|}
\hline Packaging Material & Colour & Taste & Aroma \\
\hline LDPE & 8.5 & 8.6 & 8.42 \\
\hline HDPE & 8.5 & 8.6 & 8.42 \\
\hline Glass Bottle & 8.5 & 8.6 & 8.42 \\
\hline
\end{tabular}

Table 4: Sensory scores of digestive pills on day one.

\begin{tabular}{|c|c|c|c|c|}
\hline Packaging Material & Colour & Taste & Aroma & 8.40 \\
\hline LDPE & 8.5 & 8.5 & 8.20 \\
\hline HDPE & 8.5 & 8.5 & 8.42 \\
\hline Glass Bottle & 8.5 & 8.6 & 8.42 \\
\hline
\end{tabular}

Table 5: Sensory scores of digestive pills on $30^{\text {th }}$ day.

\begin{tabular}{|c|c|c|c|}
\hline Packaging Material & Colour & Taste & Aroma \\
\hline LDPE & 8.5 & 8.4 & 8.30 \\
\hline HDPE & 8.5 & 8.5 & 8.41 \\
\hline Glass Bottle & 8.5 & 8.5 & 8.42 \\
\hline
\end{tabular}

Table 6: Sensory scores of digestive pills on $60^{\text {th }}$ day.

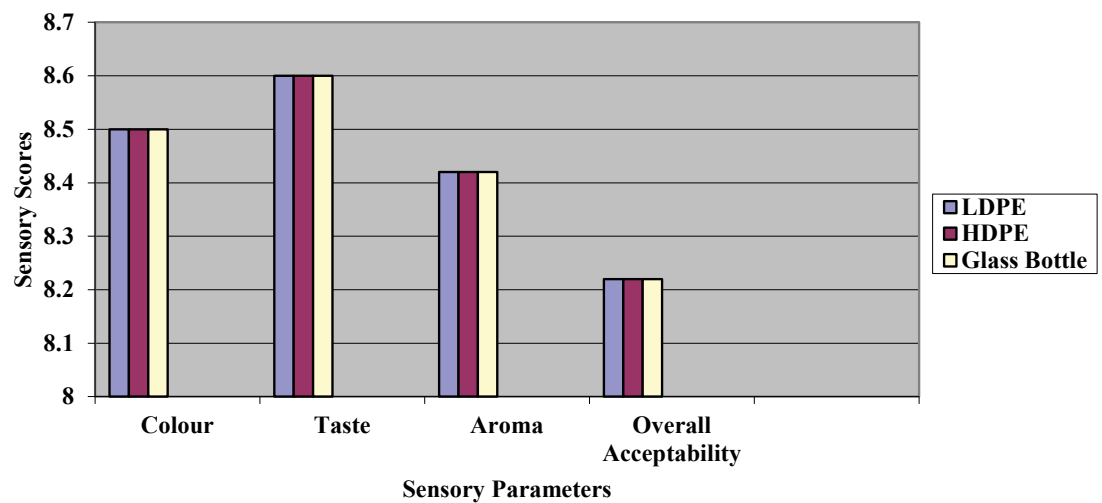

Figure 1: Sensory scores of digestive pills on day one.

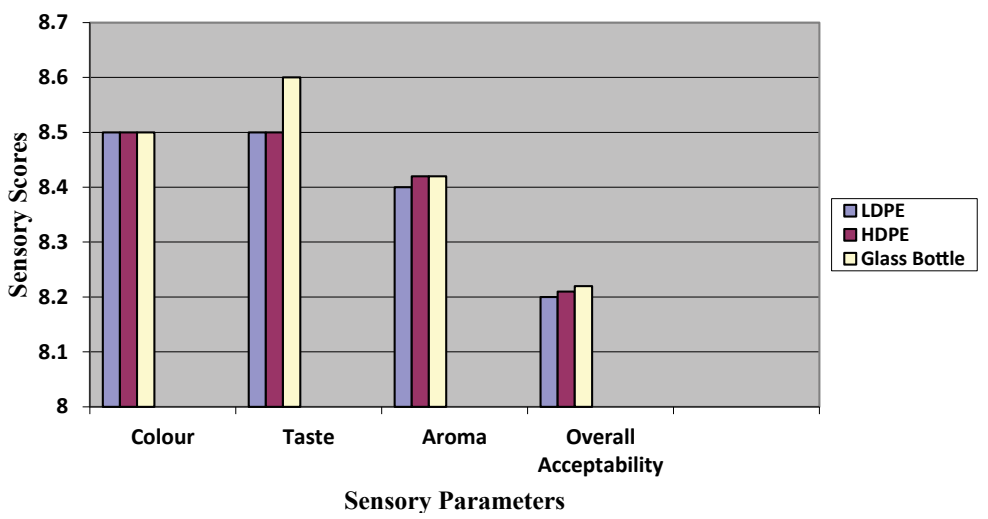

Figure 2: Sensory scores of digestive pills on $30^{\text {th }}$ day. 


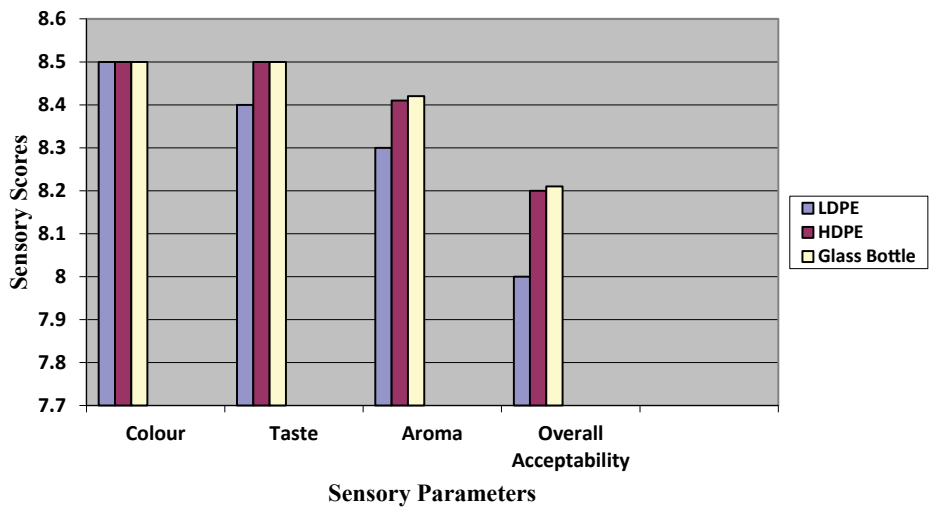

Figure 3: Sensory scores of digestive pills on 60th day.

with incorporation of other digestive ingredients which also helped the sensory characteristics to the developed digestive pills [43-45]. The sensory attributes such as colour, taste, aroma and overall acceptability was higher at initial packaging period i.e. at day one in LDPE, HDPE and Glass bottle and it was slightly decreases with increase in storage period at ambient temperature but in case of Glass bottle, it was not much affected. It was also found from Annova that the variation between the product treatments was non-significant and the variation within the product replications was significant

\section{Conclusion}

From this preliminary investigation and research, it has been concluded that the development and Physico-chemical properties of developed digestive pills have good source of protein, fat, crude fibre, carbohydrate and calories which also lies under the dietary limit of daily intake. The developed digestive pills have found satisfactory in the stomach digestion after testing their physicchemical analysis like moisture, ash, protein, fat, crude fibre, and also depended upon different sensory attributes like colour, taste, aroma, and overall acceptability during shelf life study in two months were not much effected from controlled sample i.e. Physico-chemical and Organoleptic characteristics were good and was acceptable. Thus, we concluded that the developed digestive pills were gave good response in HDPE and Glass bottle, storage at maximum storage period at ambient temperature compared than LDPE; while the extract mechanism of action remains to be elucidated in many cases of disease. The Makoi (Solanum nigrum) has wide-ranging Therapeutic properties needs to be investigated in well-designed studies and further research is in process to find more uses of Solanum nigrum.

\section{References}

1. Aguilera JM, Stanley DW (1999) Microstructural principles of food processing and engineering. Aspen Publishers Inc, Maryland, USA.

2. Kelly K, O'Mahony B, Lindsay B, Jones T, Grattan TJ, et al. (2004) Comparison of the rates of disintegration, gastric emptying, and drug absorption following administration of a new and a conventional paracetamol formulation, using $y$ scintigraphy. Pharm Res 20: 1668-1673.

3. Vassallo MJ, Camilleri M, Prather CM, Hanson RB, Thomforde GM, et al. (1992) Measurement of axial forces during emptying from the human stomach. Am J Physiol Gastrointest Liver Physiol 263: 230-239.

4. Kambizi L, Afolayan AJ (2001) An ethnobotanical study of plants used for the treatment of sexual transmitted diseases (njovhera) in Guruve District, Zimbabwe. J Ethnopharmacol 77: 5-9.

5. Rayner CK, Samsom M, Jones KL, Horowitz M (2001) Relationships of upper gastrointestinal motor and sensory function with glycaemic control. Diabetes Care 24: 371-381.
6. Agrawal KR, Lucas PW, Prinz JF, Bruce IC (1997) Mechanical properties of foods responsible for resisting food breakdown in the human mouth. Arch Ora Biol 42: 1-9.

7. Kojia M, Popovia R, Karadyia B (1997) Vaskularne biljke Srbiyekaoin dikatoristanista, Institut zaistrayivanja u polyoprivedi "Srbija" and Institut zabioloskai strayivanja "sinisa Stankovia", Beograd.

8. Lee KR, Kozukue N, Han JS (2004) Glycoalkaloids and metabolites inhibit the growth of human colon (HT29) and liver (HepG2) cancer cells. J Agric Food Chem 52: 2832-2839.

9. Ali NS, Singh K, Khan MI, Rani S (2010) Protective effect of ethanolic extracts of Solanum nigrum on the blood sugar of albino rats. IJPSR 1: 97-99.

10. Sridhar TM, Josthna P, Naidu CV (2011) Antifungal activity, phytochemical analysis of Solanum nigrum (L.)-An important antiulcer medicinal plant. J Ecobiotechnol 3: 11-15.

11. Sultana S, Perwaiz S, Iqbal M, Athar M (1995) Crude extracts of hepatoprotective plants, Solanum nigrum and Cichoriuminty businhibit free radical-mediated DNA damage. J Ethnopharmacol, 45: 189-192.

12. Atanu FO, Ebiloma UG, Ajayi El (2011) A review of the pharmacological aspects of Solanum nigrum Linn. Biotechnol Molecul Biol Rev 6: 1-7.

13. Chifundera K (1998) Livestock diseases and the traditional medicine in the Bushi area, Kivu province, Democratic Republic of Congo. Afr Study Monogr 19: 13-33.

14. Sharma YK, Singh H, Mehra BL (2004) Hepatoprotective effect of few Ayurvedic herbs in patients receiving antituberculus treatment. Indian $\mathrm{J}$ Traditional Knowledge 3: 391-396.

15. Sikdar M, Dutta U (2008) Traditional phytotherapy among the Nath people of Assam. Entno- Med 2: 39-45.

16. Cooper MR, Johnson AW (1984) Poisonous plants in Britain and their effects on animals and man. London HMSO.

17. Dhellot JR, Matouba E, Maloumbi MG, Nzikou JM, Dzondo MG, et al. (2006) Extraction and nutritional properties of Solanum nigrum L. Seed oil. Africa Biotechnol 5: 987-991.

18. Karmakar UK, Tarafder UK, Sadhu SK, Biswas NN, Shill MC (2010) Biologica investigations of dried fruit of Solanum nigrum Linn. S J Pharm Sci 3: 38-45.

19. Kaushik D, Jogpal V, Kaushik P (2009) Evaluation of activities of Solanum nigrum, fruit extract. Arch Appl Sci Res 1: 43-50.

20. Elhag RAM, Badwi MAE, Bakhiet AO, Galal M (2011) Hepatoprotective activity of Solanum nigrum extracts on chemically induced liver damage in rats. J Vet Med Ani Heal 3: 45-50.

21. Atanu U, Ebiloma, Ajayi El (2010) A Review of the Pharmacological Aspects of Solanum nigrum Linn. Biotechnology and molecular Biology Review 6: 1-7.

22. Hamil FA, Apio S, Mubiru NK, Bukenya-Ziruba R, Mosanyo M, et al. (2003) Traditional herbal drugs of southern Uganda, II. Literature analysis and antimicrobial assays. J Ethnopharmacol 84: 57-78.

23. Parveen, Upadhyay B, Roy S, Kumar A (2007) Traditional uses of medicinal plants among the rural communities of Churu district in the!ar Desert, India. J Ethnopharmacol, 113: 387-399. 
Citation: Bibhuti B, Yadav AK (2016) Study the Sensory Attributes and Shelf Life of Developed Digestive Pills from Makoi (Solanum nigrum). J Food Process Technol 7: 622. doi: 10.4172/2157-7110.1000622

Page 5 of 5

24. Patels S, Gheewala N, Suthar A, Shah A (2009) In-vitro cytotoxicity activity of Solanum nigrum extracts against Hela cell lines and Vero cell lines. Int $\mathrm{J}$ Pharm Pharmaceutic Sci 1: 38-46.

25. Purohit SS, Vyas SP (2004) Medicinal plants cultivation a scientific approach including processing and financial guidelines. Agrobios Publishers, Jodhpur, India.

26. Harborne JB (1984) Phytochemical methods: A guide to modern techniques of plant analysis. Chapman and Hall, London.

27. Hawkes JG, Edmonds JM (1972) Solanum L. Flora European University Press, Cambridge 3: 197-199.

28. Sweta P, Ashok Jain K (2011) Antifungal activity and preliminary photochemical studies of leaf extracts of Solanum nigrum Linn. Int J Pharma Pharmaceutic Sci.

29. Venkatesan D, Karrunakaran CM (2010) Antimicrobial activity of selected Indian medicinal plants. J Phytol 2: 44-48.

30. Heo KS, Lee SJ, Ko JH (2004) Glycoprotein isolated from Solanum nigrum L. inhibits the DNA-binding activities of NF-kappaB and AP-1, and increases the production of nitric oxide in TPA-stimulated MCF-7 cells. Toxicol In Vitro 18: 755-763.

31. Hussain AOD, Virmani, Pople SP (1992) Dictionary of Indian Medicinal Plants. Central Institute of Medical and Aromatic plants, Lucknow.

32. Jabar ZK, Khattak (2012) Solanum nigrum as potent therapy: A review. British J pharmacol Toxicol 3: 185-189.

33. Jain R, Sharma A, Gupta S, Sarethy IP, Gabrani R, et al. (2011) Solanum nigrum: Current perspectives on therapeutic properties. Alternat Med Rev 16: 78-85

34. Amarsingham RD, Bisset NG, Millard AH, Woods MC (1964) A phytochemica survey of Malaya-III, Alkaloids and saponins. Economic Botany 18: 270-278.

35. Arunachalam G, Subramanian N, Pazhani GP, Karunanithi M, Ravichandran
$V$, et al. (2009) Evaluation of anti-inflammatory activity of methanolic extract of Solanum nigrum (Solanaceae). Iran J Pharmaceutic Sci Sum 5: 151-156.

36. Jainu M, Devi CSS (2004) Antioxidant effect of methanolic extract of Solanum nigrum berries on aspirin induced gastric mucosal injury. Indian J Clin Biochem 19: $65-70$.

37. Ramya J, Anjali S (2011) Solanum nigrum: Current perspectives on therapeutic properties. Alternat Med review 16: 78-85.

38. Joo HY, Lim K, Lim KT (2009) Phytoglycoprotein (150 kDa) isolated from Solanum nigrum $\mathrm{L}$ has a preventive effect on dextran sodium sulfate-induced colitis in A/J mouse. J Appl Toxicol 29: 207-213.

39. Li J, Li QW, Gao DW (2009) Antitumor and immune modulating effects of polysaccharides isolated from Solanum nigrum L. Phytother Res 23: 1524-1530.

40. Paul Singh R (2012) Role of food material properties and disintegration kinetics in gastric digestion- A quest for foods for healthy benefits.

41. Rajani C, Ruby KM (2012) Solanum nigrum with dynamic therapeutic role; A Review. Int J Pharmaceutic Sci Rev Res 15: 65-71.

42. Ravi V, Saleem TM, Maiti PP, Gauthaman K, Ramamurthy J, et al. (2009) Phytochemical and pharmacological evaluation of Solanum nigrum Linn. Afri J Pharm Pharmacol 3: 454-457.

43. Rawani A, Ghosh A, Chandra G (2010) Mosquito larvicidal activities of Solanum nigrum L. leaf extract against Culex quinquefasciatus. Parasitol Res 107: 1235-1240.

44. Schilling EE, Ma QS, Andersen RN (1992) Common names and species identification in black nightshades, Solanum sect. Solanum (Solanaceae) Econ Bot 46: 223-225.

45. Sridhar TM, Josthna P, Naidu CV (2011) In vitro antibacterial activity and phytochemical analysis of Solanum nigrum (Linn.): An important antiulcer medicinal plant. J Experiment Sciences. 2: 24-29. 